\title{
Spindle Cell Metaplastic Breast Carcinoma with Leiomyoid Differentiation: A Case Report
}

\author{
Claudius Conrad $^{\mathrm{a}}$ Diane L. Miller ${ }^{\mathrm{b}} \quad$ Christina Kaiser $^{\mathrm{c}}$ \\ Karl-Walter Jauch ${ }^{d}$ Hanno Nieß ${ }^{e}$ Ralf Huss ${ }^{c, f}$ \\ aDepartment of Surgery, Massachusetts General Hospital,

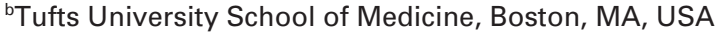 \\ 'Institute of Pathology, University of Munich, \\ ${ }^{d}$ Department of Surgery, University of Munich-Grosshadern, \\ ${ }^{\text {eDepartment }}$ of Surgery, University of Munich, \\ ${ }^{f}$ Roche Diagnostics GmbH, Penzberg, Germany
}

\section{Keywords}

Carcinoma - Leiomyoid - Metaplasia - Phylloides . Spindle Cell

\section{Summary}

Background: Metaplastic carcinoma of the breast is a rare but distinct entity within the group of undifferentiated invasive carcinomas. This entity accounts for less than $0.5 \%$ of all breast cancers and contains elements of epithelial (ductal), mesenchymal, and intermediate forms of differentiation. Of these metaplastic carcinomas, there have been reports of chondroid, squamous, osseous, and spindle differentiation. Case Report: We describe the clinical course of a 52-year-old female patient with an unusual histopathology of a spindle cell carcinoma of the breast, discuss the literature, and recommend an approach to diagnosis and treatment. The patient initially presented to an outside hospital with a rapidly growing breast mass that was originally diagnosed as a malignant phylloides tumor. She presented 11 months after the primary treatment with a local subcutaneous relapse. She later developed a local relapse of her metaplastic carcinoma in the chest wall. Extensive histopathological analysis lead to the diagnosis of a spindle cell metaplastic breast carcinoma with leiomyoid differentiation, which has not been described previously. Conclusions: Overlap in morphology can lead to a misinterpretation or underdiagnosis of metaplastic carcinomas. However, the prognosis is similar to more common types of breast adenocarcinoma.

\author{
Schlüsselwörter \\ Karzinom - Leiomyoid - Metaplasie - Phylloidtumor . \\ Spindelzelle
}

\section{Zusammenfassung}

Hintergrund: Metaplastische Mammakarzinome sind eine seltene aber eigenständige Entität innerhalb der Gruppe der undifferenzierten invasiven Karzinome. Diese Entität macht weniger als $0.5 \%$ aller Mammakarzinome aus und beinhaltet Elemente epithelialer (duktaler), mesenchymaler und intermediärer Differenzierungsformen. Es existieren Berichte von metaplastischen Karzinomen mit chondroider, squamöser, osseöser und spindelzelliger Differenzierung. Fallbericht: Wir beschreiben den klinischen Verlauf einer 52-jährigen Patientin mit der ungewöhnlichen Histopathologie eines Spindelzellkarzinoms der Brust. Außerdem werden ein Überblick über die Literatur und Empfehlungen bezüglich der Diagnose und Behandlung gegeben. Die Patientin war ursprünglich mit einem schnell wachsenden Knoten in der Brust in einem externen Krankenhaus vorstellig geworden, wo ein maligner Phylloidtumor diagnostiziert wurde. 11 Monate nach der primären Therapie wurde sie erneut mit einem lokalen, subkutanen Rezidiv vorstellig. Später kam ein lokales Rezidiv des metaplastischen Karzinoms in der Brustwand hinzu. Nach eingehender histopathologischer Untersuchung wurde ein Mammakarzinom mit Spindelzell-Metaplasie und Leiomyoid-Differenzierung diagnostiziert, was bisher noch nie beschrieben wurde. Schlussfolgerungen: Überlappende morphologische Eigenschaften können zur Fehlinterpretation bzw. Unterdiagnose metaplastischer Karzinome führen. Die Prognose ist jedoch mit der von häufiger auftretenden Arten von Adenokarzinomen der Mamma vergleichbar.

\section{KARGER \\ Fax +497614520714 \\ Information@Karger.de}

www.karger.com (c) 2011 S. Karger GmbH, Freiburg

$1661-3791 / 11 / 0063-0230 \$ 38.00 / 0$

Accessible online at:

www.karger.com/brc
Claudius Conrad, M.D. Ph.D.

Harvard Medical School and Harvard Stem Cell Institute

Department of Surgery, Massachusetts General Hospital

55 Fruit Street, GRB-425, Boston, MA 02114, USA

Tel. +617 72-62803, Fax -43499

cconrad1@partners.org,www.massgeneral.org/gensurg/ 


\section{Introduction}

The term metaplastic describes a histopathological phenotype that is unusual. Many tumors are identified as metaplastic, indicating that the tumor deviates from the native tissue of the organ where it was found. For spindle cell metaplastic carcinoma, glandular epithelium transforms into nonglandular mesenchymal tissue [1].

After the introduction of the term metaplasia by Huvos et al. [2], many terms such as carcinosarcoma were established to describe the metaplastic component of the tumor. However, even today, the terminology concerning metaplastic carcinoma is inadequate, since there is no clear-cut definition of the inclusion criteria. Further, whenever considering the diagnosis of a metaplastic tumor entity, a local collision of 2 separate tumor entities needs to be considered as well.

The difficulties concerning spindle cell carcinomas of the breast are not limited to the histopathological diagnosis. The most common clinical presentation is a large palpable mass [3], however, tumor sizes reported so far vary amongst studies. One study from Edinburgh reports tumor sizes between 2.2 and $10 \mathrm{~cm}$ [4], while patients evaluated in a South Korean study had palpable masses with a mean tumor size of $4.2 \mathrm{~cm}$ [5].

There is little data on patients who were detected by mammographic screening, and presently, there is no known specific mammographic characteristic of metaplastic cancer. Mammographic findings reported in the literature have varied between ill defined and spiculated masses. A retrospective analysis of patients with metaplastic carcinoma $(\mathrm{n}=16)$ found 15 masses and 1 clustered calcification without an associated mass [5]. In only 11 of the 15 cases diagnosed with mammography could an association be made by using ultrasound. On B-mode sonography, there was complex internal echogenicity with solid and cystic components in 6 of the 16 cases in a study by Park et al. [5] and 1 of 8 cases in a study by Günhan-Bilgen [3].

Metastasis is rare, but when dissemination occurs, it is suggested that it bypasses the lymph nodes [1]. However, Khan et al. [6] demonstrated in a case series that spindle cell carcinomas of the breast commonly metastasize to the axillary lymph nodes and that omitting node sampling may result in under-staging.

Due to the rarity of the tumor, there are no common guidelines for its treatment. Recent case series as well as large studies with more than 180 patients recognized the lack of adequate treatment options and demonstrated the aggressive nature of this carcinoma [7-10].

\section{Case Report}

One and a half years prior to presentation to our department, a 53-yearold patient discovered a rapidly growing, pea-sized lump in the inner lower quadrant of her left breast. Ultrasound and mammography revealed a tumor $3.3 \mathrm{~cm}$ in size (BI-RADS IV). The patient underwent a bioptic analysis of the tumor with subsequent operative extirpation. Histopathological diagnosis of the biopsy was 'malignant phylloides tumor.' The tumor was Ki67 20\%, G3 differentiated, HER2/neu-negative (HERCEP score 0), and estrogen and progesterone receptor-negative (immune reactive score 0 ). Due to infiltration of the skin, it was necessary to resect a substantial part of the skin overlying the tumor. An expert breast pathologist contacted for reference confirmed a diagnosis of spindle cell metaplastic carcinoma. An axillary dissection was performed, revealing 12 lymph nodes free of tumor. Final staging at this point was pT2, G3, pN0, pM0, R0. One month later, the patient was referred for radiotherapy planning. The recommendation was to perform 50/2.0 Gy thoracic wall radiation with sparing of the axilla and local electron boost $3 \times 2$ Gy. At this point, no chemotherapy was performed.

Eleven months after the initial mastectomy, the patient presented with a lump in the area of the scar from the primary mastectomy. Multislice computed tomography $(\mathrm{CT})$ imaging revealed a tumor $4.5 \times 2.0 \mathrm{~cm}$ in size extending from the thoracic wall with streaky branches into the subcutaneous tissue (fig. 1). The tumor bordered directly on the cortex of the adjacent ribs without apparent infiltration. Staging revealed no metastasis. The patient was transferred to our department where an extirpation of the tumor with resection of part of the 6th rib was performed. After the operation, the patient received a chemotherapeutic treatment with 6 cycles of epirubicin $\left(75 \mathrm{mg} / \mathrm{m}^{2}\right)$ and taxotere $\left(75 \mathrm{mg} / \mathrm{m}^{2}\right)$, which was tolerated without significant side effects.

One month after completion of her chemotherapeutic regimen, the patient developed metastasis to both lungs. The extensive progression of the lung metastasis under epirubicin and taxotere limited the therapeutic options of the oncologist to a palliative monotherapy of ifosfamide (6,000 $\mathrm{mg}$ days 1 and 2; 5,000 $\mathrm{mg}$ day 3$)$. The goals of this treatment were prolongation of survival and avoidance of tumor-associated side effects. The patient tolerated the monotherapy with ifosfamide well, so after 1 cycle of ifosfamide, cisplatin (50 mg days 4 and 5) was added. Unfortunately, the patient progressed to develop brain metastasis and died 1 year after her tumor recurrence.

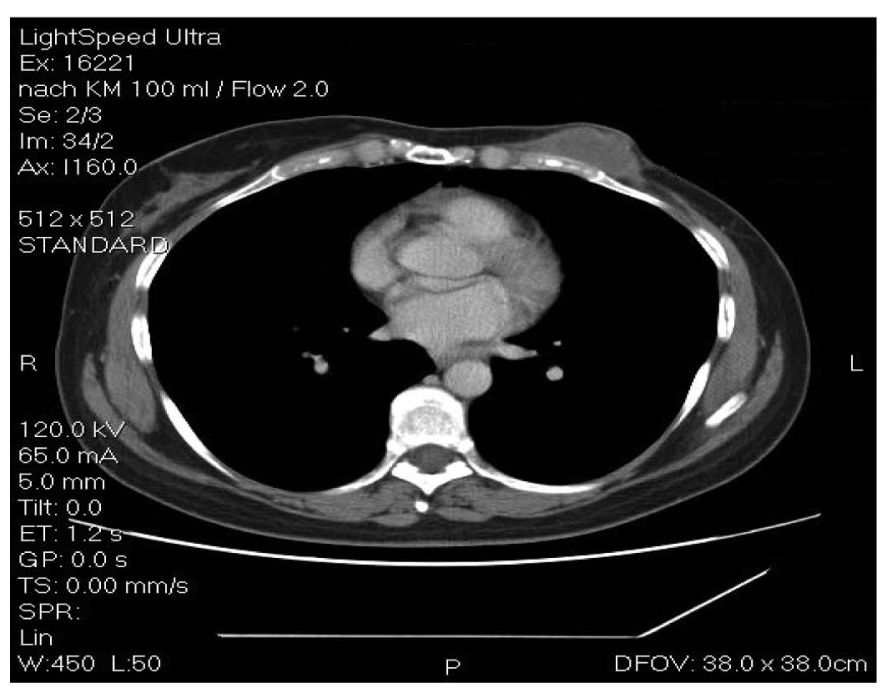

Fig. 1. Magnetic resonance imaging of the tumor relapse 11 months after the primary presentation. 

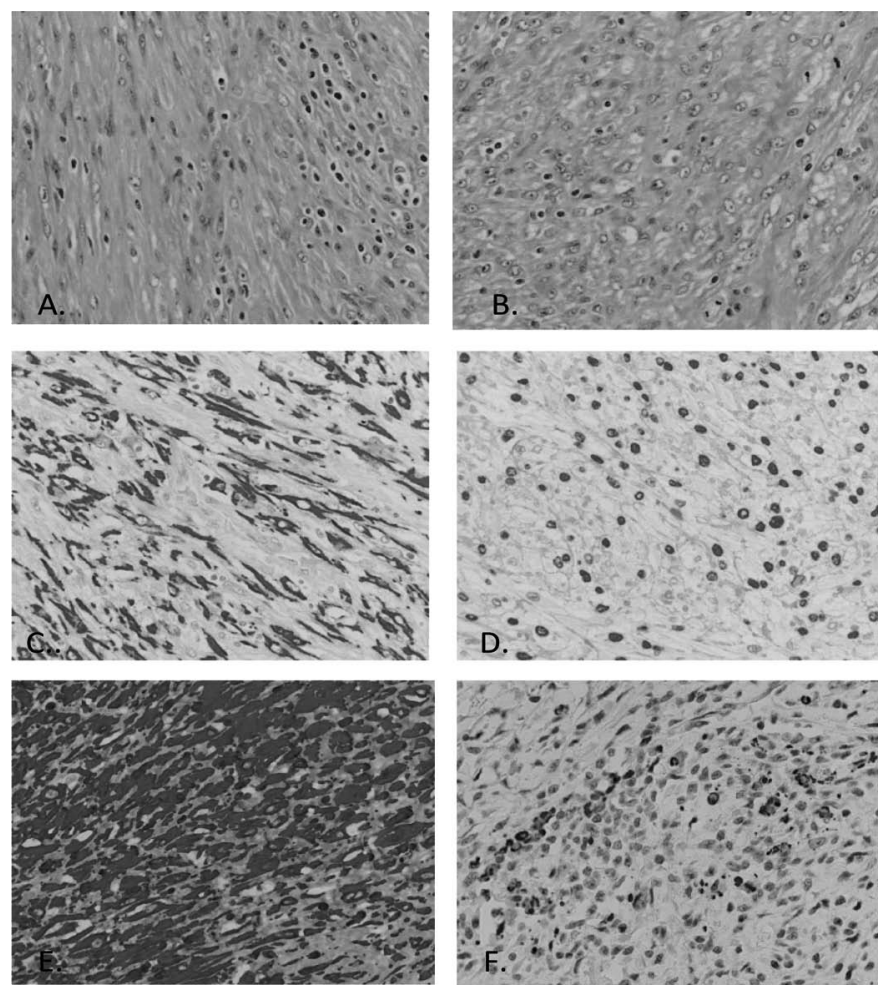

Fig. 2. Histology of the spindle cell carcinoma (hematoxylin/eosin staining): a spindle-shaped cells with myxoid amorphic matrix and hyperbasophilic nucleus, $\mathbf{b}$ vacuoles and mitosis dominating the aspect; Immunophenotyping: c staining against pancytokeratin, d p63, e vimentin, and $\mathbf{f}$ smooth muscle actin (original magnification $\times 400$ ).

\section{Pathology}

Originally the mass was diagnosed as a phylloides tumor by the pathologist in a community hospital. However, the tissue was sent to a reference pathologist for additional breast pathology, and a final diagnosis of 'spindle cell metaplastic carcinoma with leiomyoid differentiation' was reported. This diagnosis was based on light microscopy as well as immunophenotyping (fig. 2). The tumor showed spindle-shaped cells with a myxoid amorphic matrix. Moreover, there were areas with glandular complexes that can be ascribed to glandular and small ductal elements without atypia. Those areas did not appear to be part of the tumor and can be attributed to ductal hyperplasia of the epithelium. Within the tumor, there were areas with bigger polygonal cells rather than spindleshaped cells. This finding suggests that this tumor was a metaplastic carcinoma rather than a true sarcoma. To confirm the suspicion of a metaplastic carcinoma, a defined set of immunohistochemistry (IHC) staining was performed. Staining against panzytokeratin AE1/AE2 was negative initially, however, using the antibody MNF 116 we saw staining of about $10 \%$ of the spindle cells. The majority of the cells also demonstrated a strong expression of smooth muscle antigen. Desmin was negative on all slides.

The material harvested from the operation at our hospital (relapse thoracic wall) was evaluated as a connective tissue tumor with heterogeneous cell populations. The fraction of cell proliferation was $20 \%$ of epitheloid cells and $5 \%$ of the remaining cells. Like the primary tumor, the material in this sample was dominated by atypical spindle-shaped cells with a hyperbasophilic nucleus with vacuoles. The nuclei varied a great deal in shape as well as in size. In 10 high-power fields (HPF), 11 mitoses were found. IHC showed positivity for panzytokeratin, p63, vimentin, and smooth muscle actin. CK18, CD31, CD34, BCL 2, estrogen receptor, and progesterone receptor were negative, and there was no overexpression of
HER2/neu. Based on the pathological analysis, the tumor diagnosis was confirmed as metaplastic carcinoma and not a phylloides tumor.

\section{Discussion}

Spindle cell carcinomas of the breast are a rare entity within the group of metaplastic carcinomas. They can pose great diagnostic and therapeutic problems to pathologists and surgeons. The metaplastic morphology makes it hard to diagnose, and the high rate of local relapse challenges surgeons as well as oncologists. Presently, there is no clear understanding whether spindle cell metaplastic carcinoma of the breast is of epithelial or mesenchymal origin. The complex histopathogenesis makes it necessary to perform additional IHC studies to exclude metaplastic carcinoma when the diagnosis of fibromatosis, low-grade mesenchymal tumor, or even phylloides tumor is made on standard $\mathrm{H}$ and $\mathrm{E}$ preparations.

In this report, we have described the clinical course and the pathology of a spindle cell metaplastic carcinoma with an unusual leiomyoid differentiation. This rare event is often misdiagnosed as phylloides tumor because it shares common morphologic and immunophenotypical features with sarcoma. Since metastasis is rare in phylloides tumors but often occurs in spindle cell metaplastic carcinomas, the correct histopathological diagnosis is crucial. Therefore, emphasis needs to be placed on screening of local relapse as well as metastasis [11].

We recommend that IHC analysis should include a keratin panel (MNF 116, CK 14, 34 ßE12), SMA, vimentin, and AE1/ AE3 $[12,13]$. However, although these markers clearly lend themselves to narrowing the diagnosis, they are not diagnostic for metaplastic carcinoma. HER2/neu and estrogen receptor status should also be evaluated for treatment options, however, spindle cell carcinomas rarely express these hormone receptors [14]. Mammography is not useful in the diagnosis of spindle cell carcinoma of the breast but is useful for the detection of a breast mass. Metastasis to the axilla is rare in lowgrade spindle cell carcinoma and is uncommon in high-grade tumors $[5,6]$.

The options in the management of a relapse remain very limited. In the case described above, epirubicin combined with taxotere had minimal success. The role of ifosfamide should also be considered as an alternative approach to treatment. Other recommendations include wide local excision or mastectomy without axillary dissection [15], protein kinase inhibitors [14], anti-epidermal growth factor receptor drugs [16], or adjuvant radiotherapy [11], however, literature on current treatment guidelines is sparse due to the rarity of this disease.

\section{Disclosure Statement}

The authors report no conflict of interest. 


\section{References}

1 Catroppo JF, Lara JF: Metastatic metaplastic carcinoma of the breast (MCB): an uncharacteristic pattern of presentation with clinicopathologic correlation. Diagn Cytopathol 2001;25:285-291.

2 Huvos AG, Lucas JC Jr, Foote FW Jr: Metaplastic breast carcinoma. Rare form of mammary cancer. N Y State J Med 1973;73:1078-1082.

$\checkmark 3$ Gunhan-Bilgen I, Memis A, Ustun EE, Zekioglu O, Ozdemir N: Metaplastic carcinoma of the breast: clinical, mammographic and sonographic findings with histopathologic correlation. AJR 2002;178:1421-1425.

4 Kurian KM, Al-Nafussi A: Sarcomatoid/metaplastic carcinoma of the breast: a clinicopathological study of 12 cases. Histopathology 2002;40:58-64.

$\checkmark 5$ Park JM, Han BK, Moon WK, Choe YH, Ahn SH, Gong G: Metaplastic carcinoma of the breast: mammographic and sonographic findings. J Clin Ultrasound 2000;28:179-186.

6 Khan HN, Wyld L, Dunne B, Lee AHS, Pinder SE, Evans AJ, Robertson JFR: Spindle cell carcinom of the breast: a case series of a rare histological subtype. EJSO 2003;29:600-603.
7 Gobbi H, Simpson JF, Borowsky A: Metaplastic breast tumors with a dominant fibromatosis-like phenotype have a high risk of local recurrence. Cancer 1999;85:2170-2185.

-8 Foschini MP, Dina RE, Eusebi V: Sarcomatoid neoplasms of the breast: proposed definitions for biphasic and monophasic sarcomatoid mammary carcinomas. Semin Diagn Pathol 1993;10:128-136.

9 Wargotz ES, Norris HJ: Metaplastic carcinomas of the breast. III. Carcinosarcoma. Cancer 1989;64:1490-1499.

10 Wargotz ES, Deos PH, Norris HJ: Metaplastic carcinomas of the breast. II. Spindle cell carcinoma. Hum Pathol 1989;20:732-740.

11 Dave G, Cosmatos H, Do T, Lodin K, Varshney D: Metaplastic carcinoma of the breast: a retrospective review. Int J Radiat Oncol Biol Phys 2006;64:771-775.

12 Dunne B, Lee AH, Pinder SE, Bell JA, Ellis IO: An immunohistochemical study of metaplastic spindle cell carcinoma, phyllodes tumor and fibromatosis of the breast. Hum Pathol 2003;34:1009_ 1015.
13 Tse GM, Tan PH, Lui PC, Putti TC: Spindle cell lesions of the breast - the pathologic differential diagnosis. Breast Ca Res Treatment 2008;109:199207.

14 Leibl S, Moinfar F: Metaplastic breast carcinomas are negative for Her-2 but frequently expres EGFR (Her-1): potential relevance to adjuvant treatment with EGFR tyrosine kinase inhibitors? J Clin Pathol 2005;58:700-704.

5 Podetta M, D'Ambrosio G, Ferrari A, Sgarella A, Dal Bello B, Silvio Fossati G, Zonta S, Silini E, Dionigi P: Low-grade fibromatosis-like spindle cell metaplastic carcinoma: a basal-like tumor with a favorable clinical outcome. Report of two cases. Tumori 2009;95:264-267.

16 Reis-Filho JS, Milanezi F, Steele D, Savage K, Simpson PT, NeslandJM, Pereira EM, Lakhani SR, Schmitt FC: Metaplastic breast carcinomas are basal-like tumours. Histopathology 2006;49;10-21. 